\title{
Southern Hemisphere imprint for Indo-Asian summer monsoons during the last glacial period as revealed by Arabian Sea productivity records
}

\author{
T. Caley ${ }^{1,2}$, S. Zaragosi ${ }^{1}$, J. Bourget ${ }^{3}$, P. Martinez ${ }^{1}$, B. Malaizé ${ }^{1}$, F. Eynaud ${ }^{1}$, L. Rossignol ${ }^{1}$, T. Garlan ${ }^{4}$, and \\ N. Ellouz-Zimmermann ${ }^{5}$ \\ ${ }^{1}$ Université Bordeaux, CNRS, EPOC, UMR5805, 33400 Talence, France \\ ${ }^{2}$ Section Climate Change and Landscape Dynamics, Dept. of Earth Sciences, Vrije Universiteit Amsterdam, Amsterdam, \\ the Netherlands \\ ${ }^{3}$ School of Earth and Environment, CPGCO2, University of Western Australia, 35 Stirling Highway, Crawley 6009, Australia \\ ${ }^{4}$ Service Hydrographique et Océanographique de la Marine, Cellule Sédimentologie, 13 Rue du Chatellier, BP30316 29603 \\ Brest cedex, France \\ ${ }^{5}$ IFPEN, 1 and 4 Avenue de Bois Préau, 92852 Rueil-Malmaison, France
}

Correspondence to: T. Caley (t.caley@vu.nl)

Received: 11 May 2013 - Published in Biogeosciences Discuss.: 11 June 2013

Revised: 7 October 2013 - Accepted: 20 October 2013 - Published: 15 November 2013

\begin{abstract}
The monsoon is one of the most important climatic phenomena: it promotes inter-hemispheric exchange of energy and affects the economical prosperity of several countries exposed to its seasonal seesaw. Previous studies in both the Indian and Asian monsoon systems have generally suggested a dominant northern hemispheric (NH) control on summer monsoon dynamics at the scale of suborbitalmillennial climatic changes, while the forcing/response of Indian and Asian monsoons at the orbital scale remains a matter of debate. Here, six marine sediment cores distributed across the whole Arabian Sea are used to build a regional surface marine productivity signal. The productivity signal is driven by the intensity of Indian summer monsoon winds. Our results demonstrate the existence of an imprint of suborbital southern hemispheric $(\mathrm{SH})$ temperature changes (i.e. Antarctica) on the Indian summer monsoon during the last glacial period that is generally not recognized. During the last deglaciation, the NH played a more significant role. This suggests that fluctuations in the Indian monsoon are better explained in a bipolar context. The $\delta^{18} \mathrm{O}$ signal recorded in the Asian monsoon speleothem records could be exported by winds from the Indian summer monsoon region, as recently proposed in modelling exercise, explaining the $\mathrm{SH}$ signature observed in Asian cave speleothems. Contrary to the view
\end{abstract}

of a passive response of Indian and Asian monsoons to $\mathrm{NH}$ anomalies, the present results appear to suggest that the IndoAsian summer monsoon plays an active role in amplifying millennial inter-hemispheric asymmetric patterns. Additionally, this study confirms previously observed differences between Indian and Asian speleothem monsoonal records at the orbital-precession scale.

\section{Introduction}

Today, the Arabian Sea is characterized by a high sea-surface productivity. Although it is difficult to quantify the preformed $\mathrm{O} 2$ / nutrient ratio of Antarctic intermediate waters influencing the Indian sector of the Southern Ocean and its control on the Arabian Sea productivity, the seasonal wind reversal in response to Indian monsoonal dynamics is undoubtedly important for nutrient supply to the sea surface, which modulates productivity and subsurface $\mathrm{O}_{2}$ demand (Böning and Bard, 2009; Nair et al., 1989). The high surface productivity contributes to the generation of important biogenic fluxes to the sea floor, which, combined with a low supply of oxygen by physical pump, produces and maintains an intense oxygen minimum zone (OMZ) (Sarme, 2002; 
Böning and Bard, 2009) (Fig. 1). High-resolution studies, based on palaeoproductivity proxies, have documented production changes in the area linked to variability in upwelling driven by the summer monsoon (Schulz et al., 1998; Altabet et al., 2002; Ivanochko et al., 2005).

It has been long suggested that the Northern Hemisphere (NH) climate controls the Indo-Asian summer monsoon dynamics at suborbital scale (Schulz et al., 1998; Wang et al., 2001; Altabet et al., 2002; Burns et al., 2003; Rohling et al., 2003; Yuan et al., 2004; Ivanochko et al., 2005; Cosford et al., 2008; Deplazes et al., 2013) based on the apparent similarity of these Indo-Asian record structures at millennial/suborbital scale with those of Greenland $\delta^{18} \mathrm{O}$ ice-core records (NGRIP members, 2004). During warm interstadials of the North Atlantic, the atmosphere can hold more moisture as a result of higher air temperatures. In addition, the duration and intensity of winter snow cover over Asia exerts an important control on the intensity of the summer monsoon (Meehl, 1997). A minority of research results led to a different view and suggested a possible teleconnection between the Asian monsoon and Southern Hemisphere (SH) climatic variations (Cai et al., 2006; Rohling et al., 2009). However, such potential teleconnection for the Indian monsoon system is generally not recognized with an exception at the sub-Milankovitch variability (Leuschner and Sirocko, 2000). Comparison between Indo-Asian monsoon records and $\mathrm{NH}$ changes is traditionally based on a limited number of study sites (Schulz et al., 1998; Wang et al., 2001; Altabet et al., 2002; Ivanochko et al., 2005, Deplazes et al., 2013). Results are therefore reduced to localized data sets and interpretations with possible influence of regional particularities that can induce signal bias. In addition, the forcing-response relationships of Indo-Asian summer monsoons at the orbital scale also remain a matter of debate (Wang et al., 2001, 2008; Clemens et al., 2003, 2010; Cheng et al., 2009; Caley et al., 2001a, b).

Here, we analyse suborbital and orbital marine productivity records, based on bromine $(\mathrm{Br})$ signals obtained by XRF counts, in the Arabian Sea (Fig. 1). Although the chemical nature or origin of the association is unknown, bromine in the particulate phase of sediments is probably associated entirely with organic matter (Harvey, 1980; Pedersen and Price, 1980; Calvert and Pedersen, 1993; Mayer et al., 2007). It behaves conservatively within the water column and is not affected by redox changes in the water column and within the sediments (Shimmield and Pedersen, 1990, and references therein). Primary producers, especially macroalgae (Gribble, 1998), and heterotrophic organisms (invertebrates and bacteria) (Gribble, 1998; Van Pée, 1996) are known to synthesize brominated organic compounds, and the Br preservation may be subject to normal diagenetic loss of organic carbon during progressive burial (Calvert and Pedersen, 1993; Mayer et al., 2007). Nonetheless, it seems that $\mathrm{Br}$ is less labile during diagenesis than the bulk of buried organic matter (Shimmield and Pedersen, 1990). Previous studies have demonstrated a

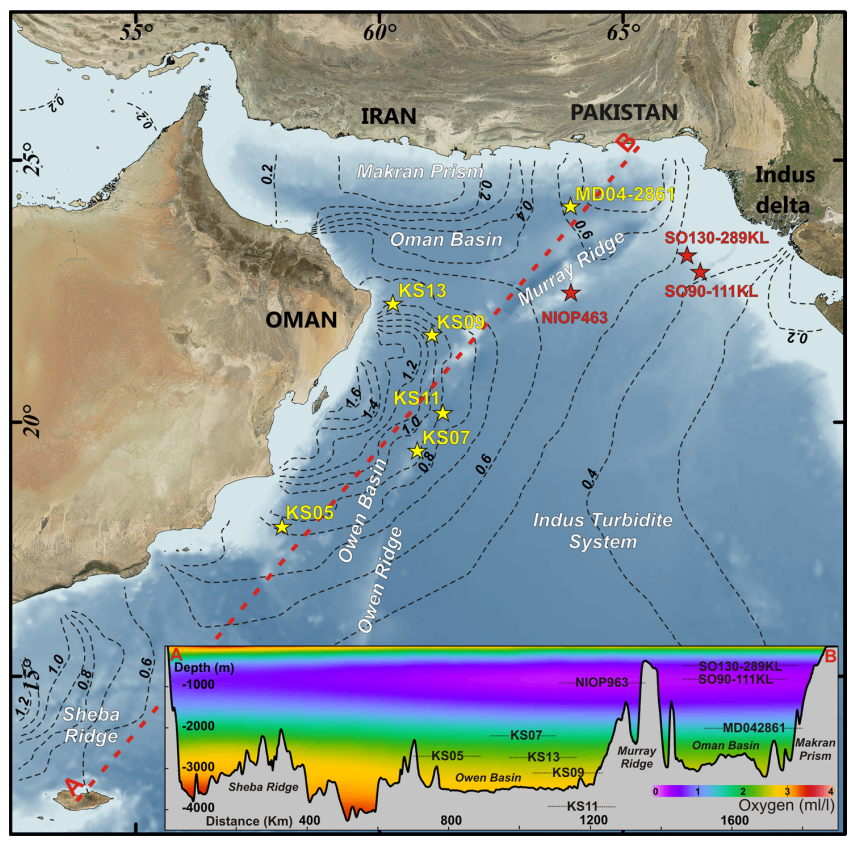

Fig. 1. Core locations in the Arabian Sea with hydrological data corresponding to Indian summer monsoon conditions. The effect of summer monsoon wind-driven upwelling of nutrient-rich subsurface waters is visible through the surface concentration in chlorophyll (black dash lines in $\mu \mathrm{g} \mathrm{L}^{-1}$; data from July, August, September derived from NOAA NODC WOA01; Conkright and Boyer, 2002). Low supply of oxygen by physical pump, combined with high surface productivity, produces an intense oxygen minimum zone (OMZ) (data for the oxygen profile are derived from the WAO05 (Garcia et al., 2006) and plot using Ocean Data View (Schlitzer, 2011)) as visible along the A-B profile. Yellow and red stars indicate the coring sites used in this study and previously published (Schulz et al., 1998; Ziegler et al., 2010; Deplazes et al., 2013), respectively.

good correlation between $\mathrm{Br}$ and sedimentary marine organic carbon (MOC) in different productive oceanic settings, for instance the Panama Basin (Pedersen and Price, 1980), the Namibian margin (Calvert and Price, 1983), the northwest African margin (Martinez et al., 1999), the Californian margin (Hendy and Pedersen, 2005) and the Arabian Sea (Ziegler et al., 2008).

We first demonstrate the dominant role of the Indian summer monsoon in driving the recorded productivity signal. Then changes in the Indian monsoon during the last $80 \mathrm{kyr}$ are investigated, together with their links to the Asian monsoon system and the potential control of bipolar $(\mathrm{NH} / \mathrm{SH})$ climate variability on monsoon dynamics. 


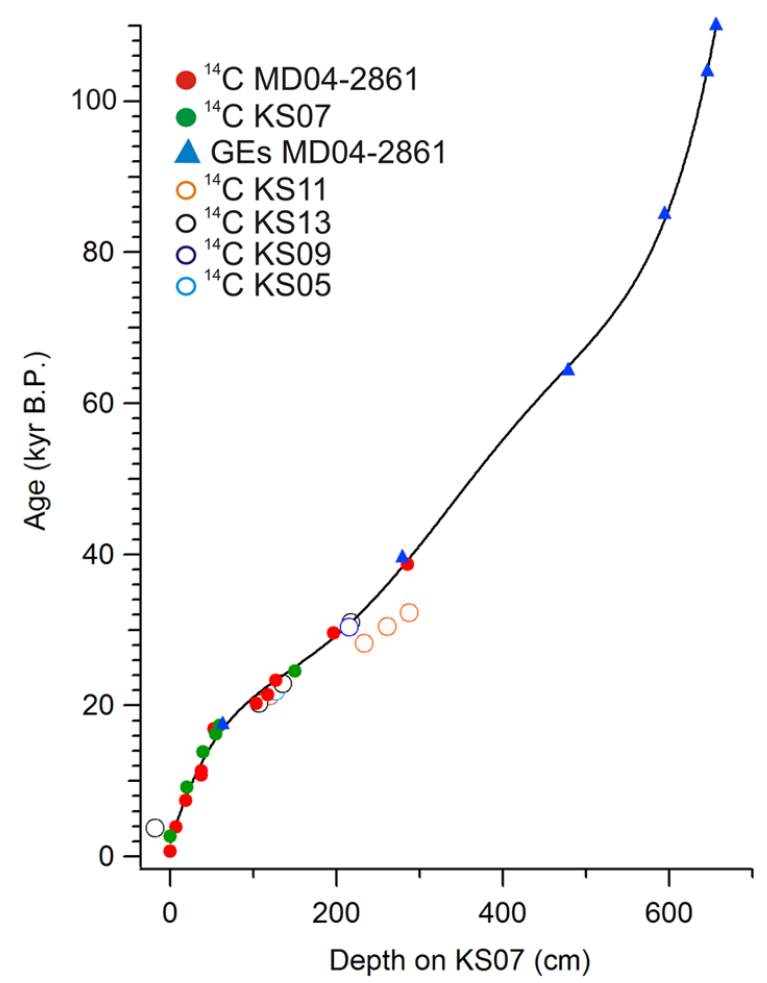

Fig. 2. Age model built with 17 radiocarbon $\left({ }^{14} \mathrm{C}\right)$ control points based on 2 different hemipelagic cores (MD04-2861 (Caley et al., 2011a) and KS07) and 6 Globorotalia event (GE) control points on core MD04-2861 (Caley et al., 2011a). Radiocarbon $\left({ }^{14} \mathrm{C}\right)$ control points for cores KS11, KS13, KS09 and KS05 are also indicated.

\section{Material and methods}

\subsection{Bromine measurements}

Bromine measurements were performed with an Avaatech XRF core scanner. Each core section was scanned every $1 \mathrm{~cm}$ (except core MD04-2861, which was scanned every $2 \mathrm{~cm}$ ) with ionization energy of 10 and $30 \mathrm{kv}$.

\subsection{Organic carbon content}

The organic carbon content was determined on dry weight sediment by combustion in a LECO CS 125 analyser (Cauwet et al., 1990). Samples were acidified in crucibles with $2 \mathrm{~N} \mathrm{HCl}$ to destroy carbonates, then dried at $60^{\circ} \mathrm{C}$ to remove inorganic $\mathrm{C}$ and most of the remaining acid and water. The analyses were performed by direct combustion in an induction furnace, and the $\mathrm{CO}_{2}$ formed was determined quantitatively by infrared absorption.

\subsection{Age models}

The age model was built with 17 radiocarbon $\left({ }^{14} \mathrm{C}\right)$ control points based on 2 different hemipelagic cores (MD04-2861 (Caley et al., 2011a) and KS07) (Table 1). Radiocarbon ages

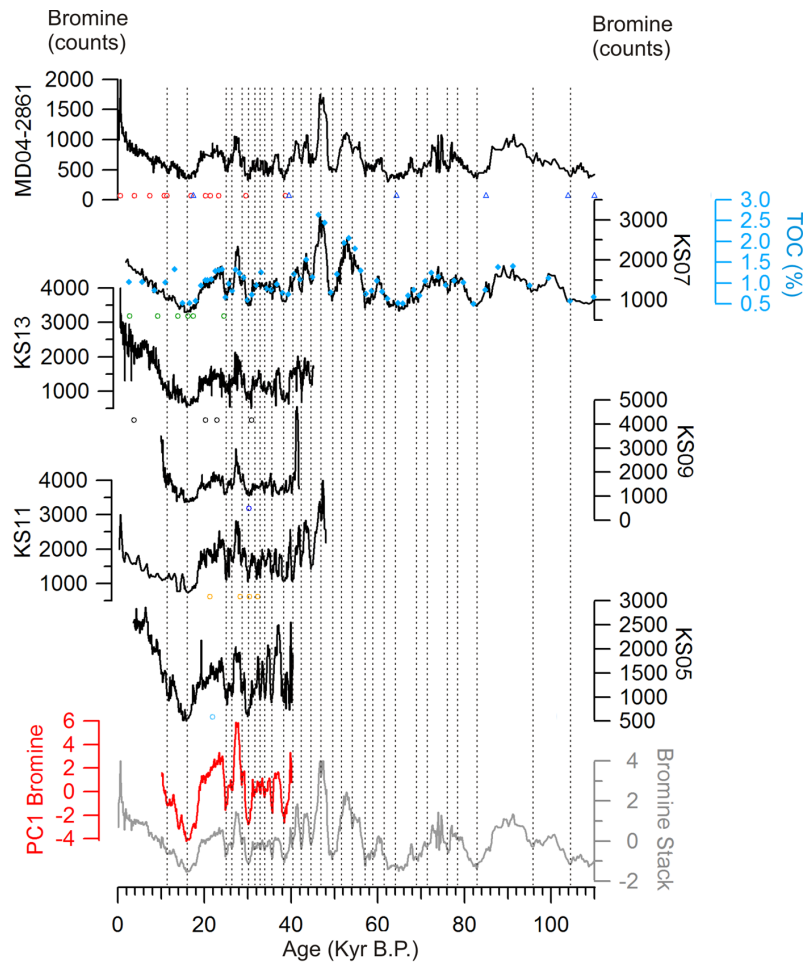

Fig. 3. Bromine signals and accompanying bromine stack and PC1bromine for the whole Arabian Sea. All the bromine XRF-count signals obtained for the six studied cores are visible for the last $110 \mathrm{kyr}$. For cores MD04-2861, KS13, KS09, KS11, KS05 and KS07, age control points are indicated by coloured circles $\left({ }^{14} \mathrm{C}\right.$ dates $)$ and blue triangles (GEs). Blue dots for core KS07 refer to total organic carbon (TOC) values. Black dashed lines indicate common events of low bromine values in each record.

were obtained at the Laboratoire de Mesure du Carbone 14 in Saclay (SacA) within the framework of the ARTEMIS radiocarbon dating project. Radiocarbon dates have been corrected for a marine reservoir effect of $400 \mathrm{yr}$ and calibrated to calendar years using CALIB Rev 6.0.1/Marine04 data set (Bard, 1998; Stuiver, 1998). All ages are given as calendar age (cal. BP). In addition, six Globorotalia event (GE) control points were used on core MD04-2861 (Caley et al., 2011a). Because downcore bromine signals in each of the six cores showed a similar structure and peaks, all core depths (MD04-2861, KS05-09-11-13) were converted to KS07 core depth by tuning each bromine record to the KS07 bromine record with the AnalySeries software (Paillard et al., 1996). Core KS07 was chosen as a reference core because (1) the core is entirely composed of hemipelagic sediments providing a continuous record over the last $110 \mathrm{ka} \mathrm{BP}$, and because (2) KS07 was not affected by coring disturbance (piston effect) during the coring procedure. Note that during the tuning procedure, some turbiditic events in cores KS09, KS11, and KS13 were virtually removed because their deposition was instantaneous on a geological scale. The stratigraphic 
Table 1. ${ }^{14} \mathrm{C}$ dating in cores KS07, KS13, KS11, KS05, KS09, and MD04-2861 (Caley et al., 2011a) and age constraints of GEs in core MD04-2861 (Caley et al., 2011a).

\begin{tabular}{|c|c|c|c|c|c|}
\hline $\begin{array}{l}\text { Depth in core } \\
\mathrm{KS} 07(\mathrm{~cm})\end{array}$ & Species & $\begin{array}{l}\text { Age }{ }^{14} \mathrm{C} \\
\text { AMS conv. } \\
\text { BP }\end{array}$ & Errors & $\begin{array}{l}\text { Calibrated } \\
{ }^{14} \mathrm{C} \text { age } \\
\text { (cal.yr BP) }\end{array}$ & Errors \\
\hline 0 & bulk & 2925 & 30 & 2713 & 50 \\
\hline 20 & bulk & 8535 & 30 & 9177 & 121 \\
\hline 40 & bulk & 12405 & 40 & 13849 & 124 \\
\hline 55 & bulk & 13620 & 50 & 16209 & 630 \\
\hline 60 & bulk & 14710 & 50 & 17384 & 335 \\
\hline 150 & bulk & 20970 & 80 & 24560 & 356 \\
\hline $\begin{array}{l}\text { Depth in core } \\
\text { MD04-2861 (cm) }\end{array}$ & Species & $\begin{array}{l}\text { Age }{ }^{14} \mathrm{C} \\
\text { AMS conv. } \\
\text { BP }\end{array}$ & Errors & $\begin{array}{l}\text { Calibrated } \\
{ }^{14} \mathrm{C} \text { age } \\
\text { (cal.yr BP) }\end{array}$ & Errors \\
\hline 10 & bulk & 1100 & 30 & 658 & 48 \\
\hline 70 & bulk & 3905 & 30 & 3877 & 96 \\
\hline 140 & G. dutertrei & 6900 & 35 & 7417 & 75 \\
\hline 250 & G. dutertrei & 9845 & 45 & 10757 & 368 \\
\hline 250 & G. ruber & 10345 & 45 & 11325 & 232 \\
\hline 340 & bulk & 14160 & 60 & 16867 & 169 \\
\hline 450 & G. ruber & 17470 & 70 & 20268 & 212 \\
\hline 480 & Praeorbulina & 18290 & 60 & 21381 & 202 \\
\hline 500 & G. ruber & 19850 & 70 & 23311 & 291 \\
\hline 640 & G. ruber & 25170 & 140 & 29597 & 409 \\
\hline 810 & G. ruber & 34170 & 260 & 38711 & 632 \\
\hline $\begin{array}{l}\text { Depth in core } \\
\mathrm{KS} 13(\mathrm{~cm})\end{array}$ & Species & $\begin{array}{l}\text { Age }{ }^{14} \mathrm{C} \\
\text { AMS conv. } \\
\text { BP }\end{array}$ & Errors & $\begin{array}{l}\text { Calibrated } \\
{ }^{14} \mathrm{C} \text { age } \\
\text { (cal.yr BP) }\end{array}$ & Errors \\
\hline 54 & bulk & 3820 & 30 & 3768.5 & 103 \\
\hline 391 & bulk & 17440 & 60 & 20247.5 & 207 \\
\hline 457.5 & bulk & 19630 & 70 & 22873.5 & 511 \\
\hline 628.5 & bulk & 26600 & 130 & 30937 & 274 \\
\hline $\begin{array}{l}\text { Depth in core } \\
\mathrm{KS} 11(\mathrm{~cm})\end{array}$ & Species & $\begin{array}{l}\text { Age }{ }^{14} \mathrm{C} \\
\text { AMS conv. } \\
\text { BP }\end{array}$ & Errors & $\begin{array}{l}\text { Calibrated } \\
{ }^{14} \mathrm{C} \text { age } \\
\text { (cal.yr BP) }\end{array}$ & Errors \\
\hline 178 & bulk & 18140 & 70 & 21245 & 346 \\
\hline 462.5 & bulk & 23850 & 90 & 28236.5 & 337 \\
\hline 512.5 & bulk & 25970 & 130 & 30409 & 280 \\
\hline 606 & bulk & 28480 & 160 & 32271 & 720 \\
\hline $\begin{array}{l}\text { Depth in core } \\
\mathrm{KS} 05(\mathrm{~cm})\end{array}$ & Species & $\begin{array}{l}\text { Age }{ }^{14} \mathrm{C} \\
\text { AMS conv. } \\
\text { BP }\end{array}$ & Errors & $\begin{array}{l}\text { Calibrated } \\
{ }^{14} \mathrm{C} \text { age } \\
\text { (cal.yr BP) }\end{array}$ & Errors \\
\hline 195 & bulk & 18730 & 70 & 21863 & 410 \\
\hline $\begin{array}{l}\text { Depth in core } \\
\text { KS09 }(\mathrm{cm})\end{array}$ & Species & $\begin{array}{l}\text { Age }{ }^{14} \mathrm{C} \\
\text { AMS conv. } \\
\text { BP }\end{array}$ & Errors & $\begin{array}{l}\text { Calibrated } \\
{ }^{14} \mathrm{C} \text { age } \\
\text { (cal.yr BP) }\end{array}$ & Errors \\
\hline 299 & bulk & 25820 & 110 & 30335.5 & 327 \\
\hline $\begin{array}{l}\text { Depth in core } \\
\text { MD04-2861 (cm) }\end{array}$ & $\begin{array}{l}\text { Globorotalia } \\
\text { events }\end{array}$ & & & $\begin{array}{l}\text { Age (Caley } \\
\text { et al., 2011) }\end{array}$ & \\
\hline 370 & GE1 & & & 17400 & \\
\hline 800 & GE3 & & & 39500 & \\
\hline 1090 & GE6 & & & 64300 & \\
\hline 1330 & GE8 & & & 85000 & \\
\hline 1430 & GE9 & & & 103900 & \\
\hline 1470 & GE10 & & & 110000 & \\
\hline
\end{tabular}


data obtained in cores MD04-2861 and KS07 were used to build a polynomial age model based on the common KS07 depth (Fig. 2). The polynomial age model was then applied to the six cores (in KS07 depth, Fig. 3). Radiocarbon ages for cores KS05, KS09, KS11 and KS13 have been also provided (Table 1) but not included in the age model because the sediments in these cores are not composed entirely of hemipelagic material. Nonetheless, the addition of these supplementary ${ }^{14} \mathrm{C}$ dates indicates no violation of our initial age model (Fig. 2).

\subsection{Uncertainties associated with marine, ice and conti- nental records}

To compare Arabian Sea marine records with the bipolar climate variability, we used the high-resolution NH NGRIP $\delta^{18} \mathrm{O}$ ice record from Greenland (NGRIP members, 2004) as well as the SH EPICA (European Project for Ice Coring in Antarctica) Dronning Maud Land (EDML) $\delta^{18} \mathrm{O}$ ice record from Antarctica (EPICA community members, 2006). The chronology (GICC05) of the $\mathrm{NH}$ record has been applied, by methane synchronization, to the SH record. The GICC05 timescale (NGRIP, apply to EDML) is layer-counted with uncertainty limits which increase with age (errors are cumulative), amounting to about $0.9 \%$ at around $12 \mathrm{kyr}$ BP to about $3.5 \%$ at around $32 \mathrm{kyr}$ BP (Rasmussen et al., 2006; Anderson et al., 2006). The uranium-thorium (U-Th) age uncertainties for the Dongge and Hulu cave records remain around $1.5 \%$ (Wang et al., 2001; Yuan et al., 2004; Wang et al., 2004; Dykoski et al., 2005). ${ }^{14} \mathrm{C}$ dating of marine cores (0 to $40 \mathrm{kyr}$ ) involves uncertainties on the order of several centuries (Table 1). Nevertheless, the uncertainties are probably more important (a couple of hundred years) because of the bioturbation influences that could have mixed information between samples, the microscopic impurities, and the assumptions about the marine reservoir age correction. GEs in core MD04-2861 have radioisotopic age constraints derived from U-Th dates based on speleothem records (Ziegler et al., 2010; Caley et al., 2011a) and assume that Arabian Sea GEs and speleothem events are temporally correlative. All these uncertainties can explain some offsets between records discussed hereafter that increase with age.

\section{Results and discussion}

\subsection{The Arabian Sea productivity signal}

After completing a calibration $\left(R^{2}=0.87\right)$ with the total organic carbon (TOC) content in the sediment (Fig. 4), we can argue for an absence or limited input of terrestrial organic carbon (Ziegler et al., 2008). Bromine (Br) signals obtained by XRF counts can be used as proxies of marine organic carbon (productivity) changes (Ziegler et al., 2008).

Comparable peaks in bromine values can be observed at 20-24 kyr and centred at $27 \mathrm{kyr}$ (Fig. 3). Between 30 and

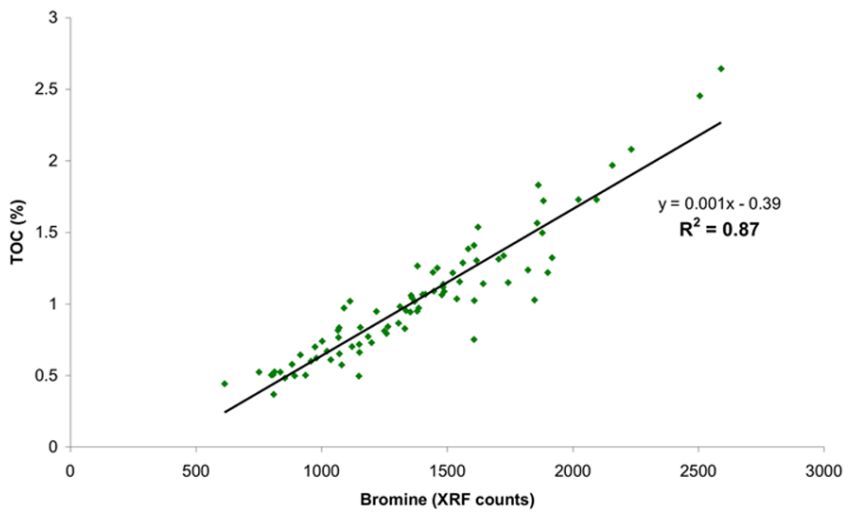

Fig. 4. Relationship between total organic carbon (TOC) (\%) and bromine XRF counts for core KS07.

$38 \mathrm{kyr}$, five events with higher bromine values are documented in each record with the event centred at $37 \mathrm{kyr}$ showing a more pronounced peak in core KS05. This prominent peak seems to be a local effect (exported production and diagenesis) as core KS13, which is located in the same basin (Owen Basin) and at the same water depth as core KS05, does not exhibit a higher peak of Br (Fig. 1). Core KS09 shows much weaker oscillation compared to the other cores that can also result from a local effect (Fig. 3). Between 40 and $50 \mathrm{kyr}$, four comparable bromine peaks are visible in core MD04-2861, KS07 and KS11 with the more pronounced peak centred at $47 \mathrm{kyr}$ (Fig. 3). Between 50 and $110 \mathrm{kyr}$, similar bromine events are observed in core MD04-2861 and KS07 (Fig. 3). Despite the different locations of the cores in very different water depths and sedimentary environments (i.e. along continental margins, deep sedimentary basins or along the Sheba-Owen-Murray ridges, Fig. 1), the common $\mathrm{Br}$ pattern registered across time and across the whole Arabian Sea indicates that comparable hydrological and sedimentological processes have driven the export and regional fossilization of this element (Fig. 1 and 3).

As downcore $\mathrm{Br}$ signals at each coring site show a very similar structure and sequence of events (peaks/troughs), a stack was computed. The stacking procedure smoothes the final signal, but it also reinforces the common down-core pattern and facilitates comparison with other records. For that purpose, each $\mathrm{Br}$ signal was resampled with a time step of 120 yr using AnalySeries software (Paillard et al., 1996). Following this, each $\mathrm{Br}$ signal was normalized into a unit standard deviation change around a zero mean, using $x$ mean divided by the standard deviation. For the obtained stack (Fig. 3), no significant effects of dilution from the input and preservation of biogenic carbonate and terrestrial material can be observed (Fig. S1).

In order to limit the smoothing effect during the stacking procedure, we used an alternative approach based on principal component analysis (PCA) with the R software (http: //www.r-project.org/) for the time period 10-40 kyr (Fig. 3). 
Table 2. Statistical tests with R software underlying the coefficient of determination $R^{2}$ and $p$ value between productivity records of the Arabian Sea and bipolar climate records (NGRIP and -EDML $\delta^{18} \mathrm{O}$ ice) for the interval 10-16 kyr and 16-40 kyr. Asterisks refer to insignificant regressions between records.

\begin{tabular}{|c|c|c|c|c|c|c|c|c|c|c|c|c|}
\hline Core & Lat & Long & Depth & $\begin{array}{r}\text { Last } 40 \mathrm{kyr} \\
\text { resolution }(\mathrm{yr})\end{array}$ & $\begin{array}{c}R^{2}-\mathrm{EDML} \\
(10-16 \mathrm{kyr})\end{array}$ & $\begin{array}{c}p \text { value } \\
- \text { EDML }\end{array}$ & $\begin{array}{r}R^{2}-\mathrm{EDML} \\
(16-40 \mathrm{kyr})\end{array}$ & $\begin{array}{c}p \text { value } \\
\text {-EDML }\end{array}$ & $\begin{array}{c}R^{2} \text { NGRIP } \\
(10-16 \mathrm{kyr})\end{array}$ & $\begin{array}{l}p \text { value } \\
\text { NGRIP }\end{array}$ & $\begin{array}{c}R^{2} \text { NGRIP } \\
(16-40 \mathrm{kyr})\end{array}$ & $\begin{array}{l}p \text { value } \\
\text { NGRIP }\end{array}$ \\
\hline KS05 & 19.4 & 60.8 & 2710 & 90 & 0.41 & 0.00 & 0.09 & 0.00 & 0.16 & 0.00 & 0.03 & $0.05^{*}$ \\
\hline KS07 & 18.0 & 58.0 & 2209 & 130 & 0.56 & 0.00 & 0.25 & 0.00 & 0.27 & 0.00 & 0.02 & 0.03 \\
\hline KS09 & 21.7 & 61.1 & 3185 & 80 & 0.64 & 0.00 & 0.25 & 0.00 & 0.36 & 0.00 & 0.02 & 0.01 \\
\hline KS11 & 20.2 & 61.3 & 4004 & 65 & 0.24 & 0.00 & 0.20 & 0.00 & 0.01 & $0.50 *$ & 0.01 & 0.01 \\
\hline KS13 & 22.3 & 60.3 & 2678 & 50 & 0.30 & 0.00 & 0.20 & 0.00 & 0.42 & 0.00 & 0.01 & 0.03 \\
\hline MD04-2861 & 24.1 & 63.9 & 2049 & 100 & 0.15 & 0.00 & 0.38 & 0.00 & 0.12 & 0.00 & 0.00 & $0.40^{*}$ \\
\hline $\begin{array}{l}\text { NIOP } 463 \\
\text { (Ziegler et } \\
\text { al., 2010) }\end{array}$ & 22.5 & 64.0 & 920 & 160 & 0.01 & $0.70 *$ & 0.12 & 0.00 & 0.16 & $0.10^{*}$ & 0.00 & $0.30^{*}$ \\
\hline $\begin{array}{l}\text { SO90-111KL } \\
\text { (Schulz et } \\
\text { al., 1998) }\end{array}$ & 23.1 & 66.5 & 775 & 90 & 0.00 & $0.90 *$ & 0.36 & 0.00 & 0.38 & 0.00 & 0.06 & 0.00 \\
\hline $\begin{array}{l}\text { SO130-289KL } \\
\text { (Deplazes et } \\
\text { al., 2013) }\end{array}$ & 23.1 & 66.5 & 571 & annual & 0.28 & 0.00 & 0.40 & 0.00 & 0.77 & 0.00 & 0.20 & 0.00 \\
\hline PC1-bromine & & & & 120 & 0.64 & 0.00 & 0.30 & 0.00 & 0.38 & 0.00 & 0.01 & 0.00 \\
\hline
\end{tabular}

The first component (PC1-bromine) of the analysis explains $75 \%$ of the variance and confirms the common pattern between Br records (Fig. 3).

\subsection{Intermediate water circulation forcing on Arabian Sea productivity}

The preformed $\mathrm{O}_{2}$ /nutrient ratio of Antarctic intermediate waters influences the Indian sector and could control Arabian Sea productivity. We focus on the interval $10-40 \mathrm{kyr}$ during the last glacial period, as age models are better constrained within this time interval. High-resolution marine sediment studies demonstrate that increases in intermediate water flow in the Arabian Sea (Jung et al., 2009) and the Indo-southwestern Pacific (Pahnke and Zahn, 2005) occurred in anti-phase with changes in Arabian Sea productivity at the suborbital scale (Fig. 5). Increased ventilation events in the SH coincide with an abrupt increase of Antarctic intermediate water renewal in the south-west Pacific sector of the Southern Ocean, and are out of phase with Arabian sea productivity increases. At the orbital scale, previous work has suggested that the $\mathrm{Br}$ signal was not in phase with increased ventilation revealed by the mid-depth benthic $\delta^{13} \mathrm{C}$ gradient (Caley et al., 2011a). Therefore, SH ventilation changes cannot be considered as the main driver of productivity changes in the Arabian Sea at the orbital- and suborbital-scale changes.

\subsection{Oxygen minimum zone and organic matter preservation}

There is presently no clear consensus concerning the effect of oxygen on the preservation of organic matter (Cowie et al., 1999, 2005; Burdige, 2007). To investigate the effect of severe oxygen depletion in the OMZ core on the preservation of the productivity signal in the Arabian Sea, we compared different published productivity records covering various water depths (Schulz et al., 1998; Ziegler et al., 2010; Deplazes et al., 2013) with our results (Figs. 1 and 6). We focus on the interval 10-40 kyr. PC1-bromine (mainly comprising records from below the modern OMZ) and the TOC record from core SO90-111KL (Schulz et al., 1998) show a generally good agreement (Fig. 6). Slight differences can be observed between 20 and $26 \mathrm{ka}$ and can be related to age model uncertainties. Records can be reconciled by a time shift of less than $2 \mathrm{kyr}$, in agreement with individual marine record uncertainties described previously. The only main differences in terms of peak amplitude can be observed between 32 and $35 \mathrm{ka}$ (Fig. 6) with higher TOC peaks in core SO90-111KL. To investigate the origin of these differences, we further compared with $\mathrm{Br}$ results from core NIOP463 (Ziegler et al., 2010) and results from core SO130-289KL (Deplazes et al., 2013). Core NIOP463 has a low resolution compared to the other records (Table 2) and only two ${ }^{14} \mathrm{C}$ dates, making it difficult to identify and discuss the Br peaks. In contrast, core SO130$289 \mathrm{KL}$ has an annual resolution and is well constrained by ${ }^{14} \mathrm{C}$ dating (Deplazes et al., 2013) (Fig. 6). Results of core SO130-289KL do not indicate higher productivity peaks at 32 and $35 \mathrm{kyr}$, and the structure of the signal is more comparable to the PC1-bromine signal rather than to the TOC signal in core SO90-111KL. Interestingly, a major peak in organic carbon can be observed at $27 \mathrm{kyr}$ in the PC1-bromine record as well as in the TOC record of core SO90-111KL but not in core SO130-289KL (Fig. 6). These three main differences (vertical lines in Fig. 6) between Arabian Sea productivity records cannot be attributed to a problem of resolution between records. Concerning a potential effect of the OMZ on the preservation of the productivity signal, we note that some differences exist between records located within the modern 


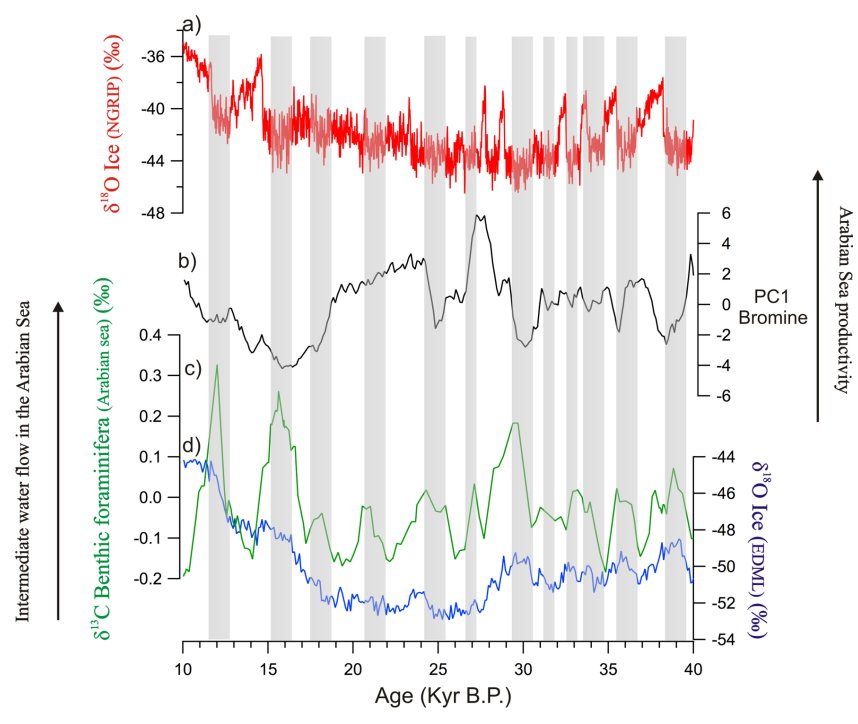

Fig. 5. Comparison between Indian summer monsoon (ISM) changes, intermediate water circulation changes and bipolar climate variability over the period $10-40 \mathrm{kyr}$. (a) NGRIP $\delta^{18} \mathrm{O}$ ice record from Greenland (NGRIP members, 2004). (b) PC1-bromine as a proxy for ISM. (c) $\delta^{13} \mathrm{C}$ as a proxy for intermediate water circulation changes in the Arabian Sea (Jung et al., 2009). (d) EPICA Dronning Maud Land (EDML) $\delta^{18} \mathrm{O}$ ice record from Antarctica (EPICA community members, 2006). Grey bars indicate increase of intermediate water flow in phase with decrease of productivity in the Arabian Sea.

OMZ (cores SO90-111KL, SO130-289KL and NIOP463) (Figs. 1 and 6). We also note that records located below the present OMZ fit with some records within the OMZ during such different events (peak at $27 \mathrm{kyr}$ for example) (Fig. 6). In addition, a key argument for a minor role of the OMZ in driving the preservation of organic matter is the observation that records below and within the present OMZ co-varied with other surface productivity records (Reichart et al., 1998; Caley et al., 2011; see also Pichevin et al., 2007). Therefore, it can be suggested that (1) the dynamics of the OMZ in the past is not the main driver of the organic carbon preservation signals observed in marine records, and (2) the potential effect of bioturbation under the OMZ is weak.

As terrestrial organic matter is poor in $\mathrm{Br}$ compared to marine organic matter (Mayer et al., 2007), a preferential input or degradation of terrestrial organic matter affecting the TOC record in cores located close to the Indus River (SO90$111 \mathrm{KL}$ and SO130-289KL) could explain some of the differences between the $\mathrm{Br}$ records (Figs. 1 and 6). However, core SO90-111KL and SO130-289KL exhibit some differences in terms of amplitudes of events, despite their location in the same area close to the Indus River (Figs. 1 and 6). In addition, the similarity between PC1-bromine event at $27 \mathrm{kyr}$ and that observed in core SO90-111KL, together with the similarity between the PC1-bromine event at 32 and $35 \mathrm{kyr}$ in

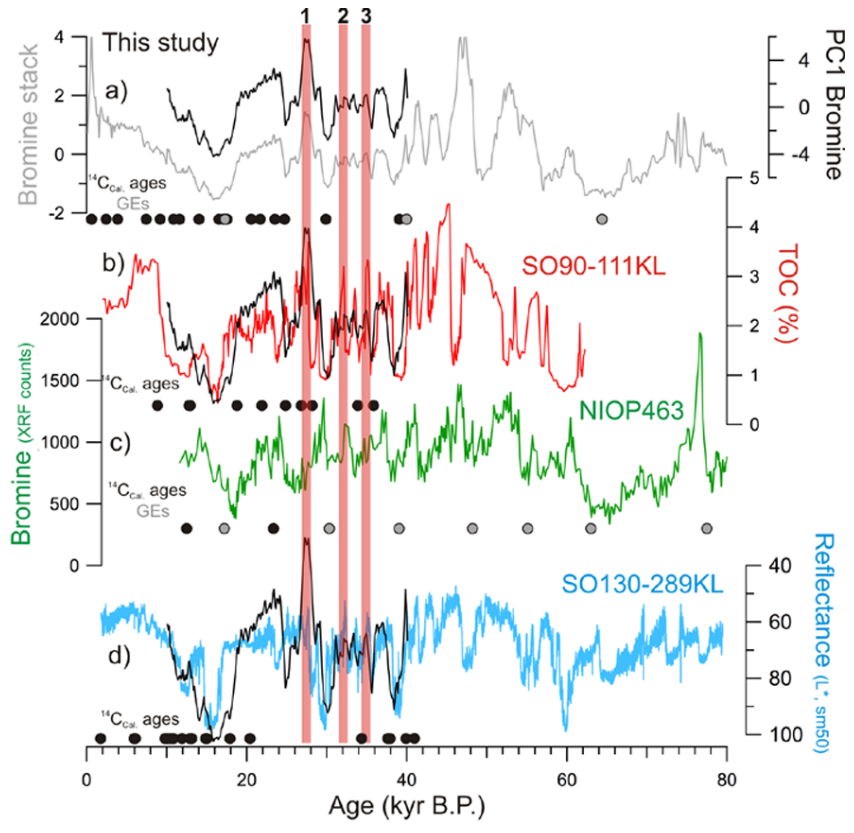

Fig. 6. Relationship between bromine stack and PC1-bromine and previously published productivity records in the Arabian Sea. (a) Bromine stack and PC1-bromine data from the present study. (b) Total organic carbon (TOC) at site SO90-111KL (Schulz et al., 1998) (see Fig. 1 for location). PC1-bromine (black) was superimposed for comparison. (c) Bromine stack of core NIOP463 (Ziegler et al., 2010) in the OMZ (Fig. 1). (d) Reflectance at site SO130289KL (Deplazes et al., 2013) (see Fig. 1 for location). PC1bromine (black) was superimposed for comparison. Radiocarbon $\left({ }^{14} \mathrm{C}\right.$ dates) and $\mathrm{GE}$ control points for each record are indicated by black and grey dots. The three red frames indicate significant amplitude differences between Arabian Sea records.

this core and in core SO130-289KL (Fig. 6), argues against a preferential input or degradation of terrestrial organic matter.

We suggest that the discrepancies between records reflect the effect of local conditions (mainly exported production and secondly diagenesis) that can induce signal bias. If true, our strategy based on the extraction of the common variance between different records appears to be a good approach that facilitates the comparison of the present and earlier results. Indeed, our results based on PC1-bromine capture the peaks of core SO130-289KL at 32 and $35 \mathrm{kyr}$, which are not apparent in core SO90-111KL but also capture the major peak at $27 \mathrm{kyr}$, which is visible in core SO90-111 KL and in our six separate bromine records (Fig. 3) but not in core SO130289KL.

To summarize, $\mathrm{SH}$ ventilation changes and the dynamics of the OMZ cannot be invoked as the main drivers of the generation and preservation of productivity signals in the Arabian Sea. Variability in upwelling, induced by summer monsoon dynamics, seems to explain the observed productivity signals most convincingly. 


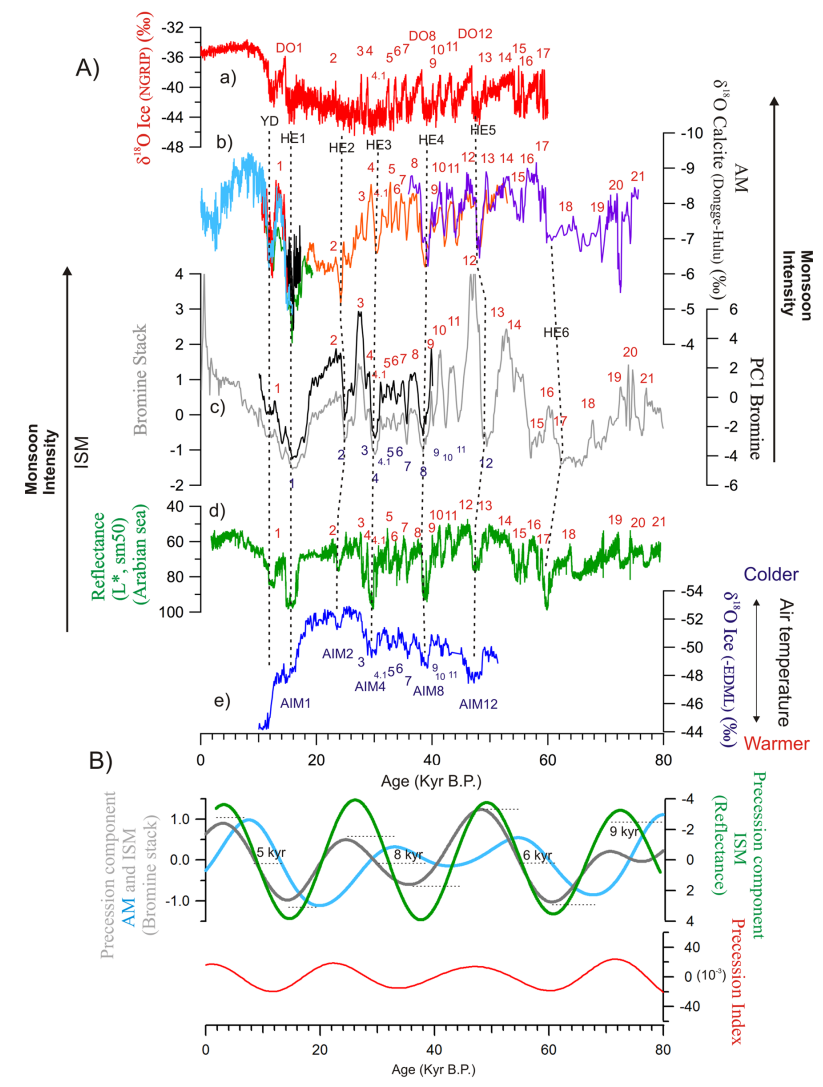

Fig. 7. Comparison between Indian summer monsoon (ISM) changes, the Asian monsoon (AM) and bipolar climate variability over the last $80 \mathrm{kyr}$. (A-a) NGRIP $\delta^{18} \mathrm{O}$ ice record from Greenland (NGRIP members, 2004). (A-b) Chinese speleothem $\delta^{18} \mathrm{O}$ calcite record (Wang et al., 2001, 2004; Yuan et al., 2004; Dykoski et al., 2005) as a proxy for AM. (A-c) Bromine stack and PC1-bromine as a proxy for ISM. (A-d) Reflectance record as a proxy for ISM (Deplazes et al., 2013). (A-e) EPICA Dronning Maud Land (EDML) $\delta^{18} \mathrm{O}$ ice record from Antarctica (EPICA community members, 2006) (note that the scale is inverted). Dansgaard-Oeschger (DO) events and Antarctic isotope maxima (AIMs) are labelled according to NGRIP members (2004) and EPICA community members (2006). The Younger Dryas and Heinrich events (HEs 1-6) are also indicated. (B) Precession component of the ISM and AM after tuning the millennial bromine stack events to the Chinese speleothem $\delta^{18} \mathrm{O}$ calcite events. The precession component of the reflectance record (Deplazes et al., 2013) on its original age scale is also visible for comparison. Dashed lines indicate a time gap between Indian and Asian records in the precession band. A relatively constant gap of $7 \mathrm{kyr}$ on average is evident. The precession index is also indicated (Laskar et al., 2004).

\subsection{Atmospheric forcing on Arabian Sea productivity}

\subsubsection{Suborbital-millennial forcing for Indian summer monsoon}

The Arabian Sea Br stack and PC1-bromine show suborbital variations that follow similar trends to the millennial-scale signal structure visible in Chinese speleothems and in Greenland/Antarctic $\delta^{18} \mathrm{O}$ ice-core records (Dansgaard, 1993; Wang et al., 2001; NGRIP members, 2004; EPICA community members, 2006)(Fig. 7). Low Br intensities seem to be recorded during events coinciding with DansgaardOeschger stadials and the Younger Dryas (or during out-ofphase Antarctic warming), including pronounced events of massive ice-rafted debris deposition in the North Atlantic, the so-called Heinrich events (HEs 1 to 6) (Heinrich, 1988) (Fig. 7).

We focus on the $10-40 \mathrm{kyr}$ interval in order to discuss suborbital-millennial changes during the last glacial period (Fig. 7). We performed regressions underlying the coefficient of determination $\left(R^{2}\right)$ and $p$ values between Arabian Sea marine records and NH NGRIP-SH EDML $\delta^{18} \mathrm{O}$ ice records over the intervals $16-40 \mathrm{kyr}$ and $10-16 \mathrm{kyr}$ (deglaciation period). Although the coefficients of determination and $p$ values between $\mathrm{Br}$ records, NGRIP and -EDML $\delta^{18} \mathrm{O}$ signals can vary (Table 2 ) as a consequence of the resolution and local effect for each record, statistical analyses for the interval 16-40 kyr always reveal better correlations between $\mathrm{Br}$ records (and PC1-bromine) and the -EDML atmospheric signal than between $\mathrm{Br}$ records (and PC1-bromine) and the NGRIP atmospheric signal (Table 2). The same observation is true for the $\mathrm{Br}$ record of Ziegler et al. (2010), the TOC record of Schulz et al. (1998) and the reflectance record of Deplazes et al. (2013) on their own age model (Table 2). Note that for the majority of these records, the resolution is high enough (lower than or equal to $100 \mathrm{yr}$ ) to allow comparison with the NGRIP record. This is particularly true for the record of Deplazes et al. (2013), which has an annual resolution, even better than the resolution of the NGRIP record.

A structure characterized by a distinct gradual shift from about 22-16 kyr is also observed in the PC1-bromine record. This is not visible in NGRIP but is similar to that recorded in the -EDML ice record (Fig. 7). The study of Deplazes et al. (2013) reveals a strong correspondence between the Arabian Sea monsoonal record and NGRIP $\delta^{18} \mathrm{O}$ but concludes that the characteristic sawtooth structure of NGRIP $\delta^{18} \mathrm{O}$ variability is not a good template for tropical hydroclimate change. Our comparison reveals a similar structure between the reflectance record and -EDML from about 22$16 \mathrm{kyr}$ (Fig. 7). We hypothesize that the differences between NGRIP $\delta^{18} \mathrm{O}$ and the reflectance record (Deplazes et al., 2013) could reflect the imprint of the SH, explaining the significant relationship with-EDML over the interval 16-40 kyr (Table 2).

These similarities indicate that $\mathrm{SH}$ changes might play an important role in Indian summer monsoon dynamics (Table 2) contrary to the traditional views of a strict $\mathrm{NH}$ control but corroborating the results for sub-Milankovitch variability of Leuschner and Sirocko (2000). Results are congruent with both modern observations (Xue et al., 2004) and high-resolution continental Quaternary records from southwestern China (An et al., 2011), which demonstrated that 

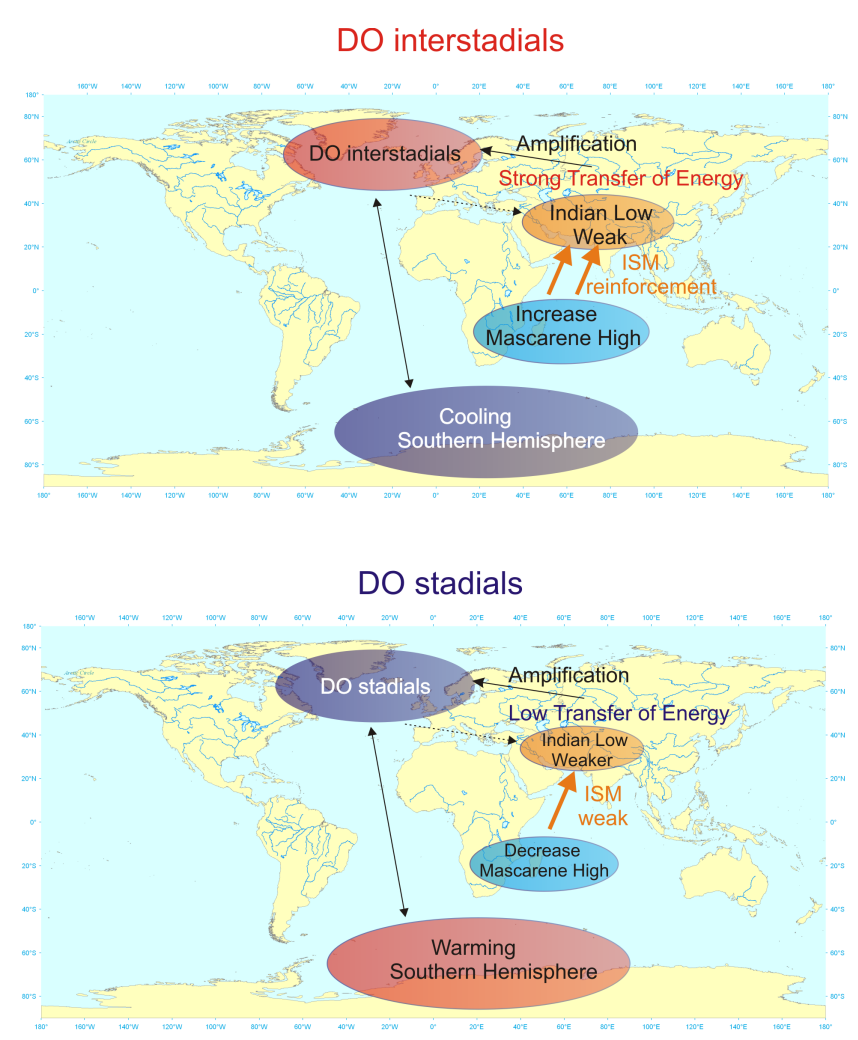

Fig. 8. A conceptual scheme showing how the Indo-Asian monsoon can play an active role to amplify inter-hemispheric energy transfer for suborbital changes during the last glacial period.

lower Antarctic temperatures lead to a stronger high pressure system over the Mascarene region. Indeed, the Mascarene high is forced by the subsiding branch of the SH Hadley cell owing to the Equator-to-Antarctica temperature gradient. This strengthens the cross-equatorial Somali jet leading to increased intensity of Indian summer monsoons (Xue et al., 2004).

Our results do not exclude a role for the $\mathrm{NH}$ in monsoon dynamics, although correlations with NGRIP are weaker (Table 2). For the interval 10-16 kyr, corresponding to the deglaciation period, the role of NH (correlation with NGRIP signal) becomes more important (Table 2, Fig. 7) as also observed by Caley et al. (2013). When the global ice volume decreases, the continental Indian low-pressure system intensifies rapidly and thus enhances the cross-equatorial monsoon gradient, together with an increased moisture supply from the warming tropical Indian Ocean (An et al., 2011).

\subsubsection{Suborbital-millennial Indo-Asian summer monsoon relationship}

Recent statistical re-evaluations of the $\delta^{18} \mathrm{O}$ signal of Asian speleothems demonstrated that this record contains information linked to $\mathrm{SH}$ at suborbital scale (Cai et al., 2006; Rohling et al., 2009). Results from this study support the idea that the atmospheric $\delta^{18} \mathrm{O}$ signal is exported by the Indian summer monsoon winds towards the Asian monsoon system, as recently shown by numerical modelling (Pausata et al., 2011; Lee et al., 2012), explaining the synchronicity between the Indian and Asian monsoon millennial events (Fig. 7). This would explain the agreement with modern meteorological data indicating that the two monsoon systems are linked through a common humidity source located in the South Indian Ocean (Ding et al., 2004; Clemens et al., 2010). One implication of this different view of the paradigm for $\mathrm{NH}$-triggered suborbital monsoon variability is the more active role played by the Indo-Asian monsoon in inter-hemispheric variability, as opposed to a passive response driven by NH-generated anomalies (Cheng et al., 2009; Pausata et al., 2011).

This study argues that the Indo-Asian monsoon can be considered as an amplifier of inter-hemispheric energy transfer at suborbital scale during the last glacial period. During a glacial period, the monsoon is weak overall (An et al., 2011). The asynchronous relationship between Antarctic and Greenland millennial-scale temperature changes during the last glacial period has led to the theory that the bipolar seesaw acts to redistribute heat according to the state of the Atlantic meridional overturning circulation (AMOC) (Crowley, 1992; Broecker, 1998). We propose that atmospheric teleconnection can amplify this process and that the Indo-Asian monsoon plays an important role (Fig. 8). During SH cooling, the monsoon circulation is enhanced as a result of a weaker Indian low caused by the $\mathrm{NH}$ temperature rise characteristic of interstadials and the increase in the Mascarene high (Fig. 8). This generates important energy transfers to the NH, which can, in turn, amplify/modulate DO interstadials (Figs. 7 and $8)$. This atmospheric teleconnection has already been suggested for DO interstadials 12, 8, and 1 (Rohling et al., 2003). Conversely, when the SH temperature increases (Antarctic isotope maxima - AIMs), the reduced Indo-Asian monsoon circulation caused by a weaker Indian low and weaker Mascarene high can constitute a positive feedback to the observed stadials recorded in the $\mathrm{NH}$ (Figs. 7 and 8). As atmospheric processes are faster than oceanic processes, the monsoon is an ideal candidate to amplify inter-hemispheric asymmetric patterns during millennial-scale changes.

\subsubsection{Orbital forcing for Indo-Asian summer monsoons}

Superimposed on the suborbital/millennial dynamics, the external (insolation) forcing contributes to Indo-Asian summer monsoon variability. Differences in the amplitude of millennial events can be observed between Indian and Asian monsoon records (Fig. 7). This could be attributed to local influence on speleothem $\delta^{18} \mathrm{O}$ signals, or to superimposed orbitally driven insolation variations. As long as other Asian speleothem records reveal an overall positive signal similarity (Cosford et al., 2008), the observed dissimilarity can be attributed to the effect of orbital variations. Furthermore, 
previous studies have reported significant differences at the orbital scale between the Indian and Asian monsoon systems (Reichart et al., 1998; Clemens and Prell, 2003; Clemens et al., 2010; Ziegler et al., 2010; Caley et al., 2011a, b).

Considering (1) the time period covered by our productivity stack and (2) that the East Asian monsoon and Indian monsoon records show a good phase relationship in the obliquity band (Clemens et al., 2010; Caley et al., 2011a, b), we have concentrated our effort on the controversial phase relation observed in the precession band. Different explanations have been put forward for these phase relationships. Reichart et al. (1998) proposed that the Indian summer monsoon was sensitive to late summer insolation forcing ( $\mathrm{Au}-$ gust or September perihelion), based on the observation that the maximum in seasonal biological productivity measured in sediment traps occurs in August and September. However, Clemens and Prell (2003) demonstrate that the late timing of the maximum biological flux within the seasonal cycle is not a synchronous response to late summer insolation forcing and should not be extrapolated to processes operating on orbital timescales. Also, Clemens and Prell (2003) and more recently Caley et al. (2011a) suggested that the combined effect of sensitive heating over the Tibetan Plateau, which is influenced by ice volume changes, and the latent heat export from the southern Indian Ocean sets the timing of strong Indo-Asian summer monsoons within the precession cycle. Caley et al. (2011a) also demonstrate that the productivity signals in the northern Arabian Sea are mainly controlled by summer monsoon dynamics and not AMOCmodulated nutrients at orbital-scale changes as hypothesized by Ziegler et al. (2010).

We have used the observed synchrony between the Indian and Asian monsoon suborbital events to advance this debate. Thus, the age model has been refined by tuning the Arabian Sea $\mathrm{Br}$ stack to the $\delta^{18} \mathrm{O}$ millennial events of speleothems (Fig. S2). This method enables the high-precision comparison of the Indian and Asian records over a common and orbitally independent age scale. The signals have then been filtered in the precession band using a Gaussian filter with AnalySeries software (Paillard et al., 1996) (Fig. 7). We also apply the same filter to the high-resolution Indian summer monsoon record of Deplazes et al. (2013), which is independent of our age model (Fig. 7). Strong differences in the precession band occur over the last $80 \mathrm{kyr}$ (Fig. 3) between Indian and Asian monsoon records, whereas the two independent Indian monsoon records show the same phasing. A constant gap of $7 \mathrm{kyr}$ on average is observed between the Indian and Asian monsoon records (Fig. 7b), reconfirming that the previous observed discrepancy (Clemens et al., 2010; Ziegler et al., 2010; Caley et al., 2011a) was not a result of age model problems. The Indian and Asian summer monsoon systems show important linkages at suborbital (this study and Deplazes et al., 2013) and orbital obliquity timescales (Clemens et al., 2010; Caley et al., 2011a). Therefore, climate processes occurring at the orbital-precession scale, and not directly related to Indo-Asian summer monsoon dynamics, probably account for the observed $7 \mathrm{kyr}$ gap (Fig. $7 \mathrm{~b}$ ). The influence of seasonality in precipitation amount and isotopic composition recorded by Asian speleothems could constitute a potential explanation (Clemens et al., 2010; Caley et al., 2011a). Modern precipitation within the cave region shows that each season accounts for a certain percentage of annual precipitation with different moisture sources and unique isotopic compositions (Clemens et al., 2010). Following this hypothesis, the SH dynamics could play an important role in controlling orbital-scale Indian summer monsoon dynamics (Clemens and Prell, 2003; Clemens et al., 2010; Caley et al., 2011a) by increasing the latent heat export from the southern Indian Ocean. Alternatively, recent modelling work suggests that El Niño-Southern Oscillation can influence the precession-scale variability and explain the phase differences between monsoon proxies, particularly between the northern and southern East Asian summer precipitation region (Shi et al., 2012).

\section{Conclusions}

Using six sedimentary bromine records along the Arabian Sea, we demonstrate the regional importance of the Indian monsoon, rather than changes in intermediate water circulation or OMZ dynamics at suborbital scales, in driving the recorded productivity signal.

The Indian monsoon records exhibit the imprint of suborbital Southern Hemisphere (SH) temperature dynamics (i.e. Antarctica) during the last glacial period, a pattern also visible in Asian monsoon record. The $\delta^{18} \mathrm{O}$ signal recorded in the Asian monsoon speleothem records could be exported by winds from the Indian summer monsoon region explaining the SH signature. The Indo-Asian monsoon seems better explained in a bipolar context and could therefore be considered as an amplifier of inter-hemispheric energy transfer at suborbital scale.

Further work is necessary to constrain better the influence of seasonality and internal feedback on the different monsoonal regions at the precession cycle. Nevertheless, this study demonstrates that the Indo-Asian summer monsoon could be a coupled ocean/atmosphere mechanism capable of amplifying inter-hemispheric asymmetric patterns.

\section{Supplementary material related to this article is available online at http://www.biogeosciences.net/10/ 7347/2013/bg-10-7347-2013-supplement.pdf.}

Acknowledgements. All scientists, technicians and crew members of the R/Vs Marion Dufresne and Beautemps Beaupré are acknowledged for technical assistance during the CHAMAK and 
Fanindien cruises. The ARTEMIS radiocarbon dating project is acknowledged. Financial contribution from the CNRS INSU LEFE-EVE programme MOMIES is acknowledged. The authors would like to acknowledge the three anonymous referees and the editor for their suggestions and comments which help to significantly improve the final manuscript.

Edited by: A. Gooday

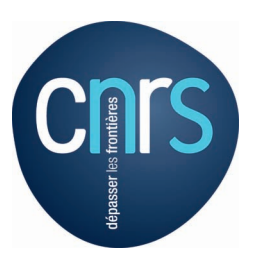

The publication of this article is financed by CNRS-INSU.

\section{References}

Altabet, M. A., Higginson, M. J., and Murray, D. W.: The effect of millennial-scale changes in Arabian Sea denitrification on atmospheric $\mathrm{CO}_{2}$, Nature, 415, 159-162, 2002.

An, Z., Clemens, S. C., Shen, J., Qiang, X., Jin, Z., Sun, Y., Prell, W. L., Luo, J., Wang, S., Xu, H., Cai, Y., Zhou, W., Liu, X., Liu, W., Shi, Z., Yan, L., Xiao, X., Chang, H., Wu, F., Ai, L., and Lu, F.: Glacial-Interglacial Indian Summer Monsoon Dynamics, Science, 333, 719-723, doi:10.1126/science.1203752, 2011.

Andersen, K. K., Svensson, A., Johnsen, S. J., Rasmussen, S. O., Bigler, M., Röthlisberger, R., Ruth, U., Siggaard-Andersen, M.-L., Steffensen, J. P., Dhal-Jensen, D., Vinther, B. M., and Clausen, H. B.: The Greenland Ice Core Chronology 2005, 1542 ka. Part 1: constructing the time scale, Quat. Sci. Rev., 25, 3246-3257, 2006.

Bard, E.: Geochemical and geophysical implications of the radiocarbon calibration, Geochim. Cosmochim. Acta, 62, 2025-2038, 1998.

Böning, P. and Bard, E.: Millennial/centennial-scale thermocline ventilation changes in the Indian Ocean as reflected by aragonite preservation and geochemical variations in Arabian Sea sediments, Geochimica et Cosmochimica Acta, 73, 6771-6788, 2009.

Broecker, W. S.: Paleocean circulation during the last deglaciation: A bipolar seesaw?, Paleoceanography, 13, 119-121, 1998.

Burdige, D. J.: Preservation of organic matter in marine sediments: controls, mechanisms, and an imbalance in sediment organic carbon budgets?, Chem. Rev., 107, 467-485, 2007.

Burns, S. J., Fleitmann, D., Matter, A., Kramers, J., and Al-Subbary, A. A.: Indian Ocean climate and an absolute chronology over Dansgaard/Oeschger Events 9 to 13, Science, 301, 1365-1367, 2003.

Cai, Y., An, Z., Cheng, H., Edwards, L. R., Kelly, M. J., Liu, W., Wang, X., and Shen, C. C.: High-resolution absolute-dated Indian Monsoon record between 53 and $36 \mathrm{ka}$ from Xiaobailong Cave, southwestern China, Geology, 34, 621-624, 2006.

Caley, T., Malaizé, B., Zaragosi, S., Rossignol, L., Bourget, J., Eynaud, F., Martinez, P., Giraudeau, J., Charlier, K., and EllouzZimmermann, N... New Arabian Sea records help decipher orbital timing of Indo-Asian monsoon, Earth Planet. Sci. Lett., 308, 433-444, doi:10.1016/j.eps1.2011.06.019, 2011a.
Caley, T., Malaizé, B., Revel, M., Ducassou, E., Wainer, K., Ibrahim, M., Shoeaib, D., Migeon, M., and Marieu, V.: Orbital timing of the Indian, East Asian and African boreal monsoons and the concept of a "global monsoon", Quat. Sci. Rev., 30, 3705-3715, doi:10.1016/j.quascirev.2011.09.015, 2011 b.

Caley, T., Malaizé, B., Kageyama, M., Landais, A., and MassonDelmotte, V.: Bi-hemispheric forcing for Indo-Asian monsoon during glacial terminations, Quat. Sci. Rev., 59, 1-4, 2013.

Calvert, S. E. and Pedersen, T. F.: Geochemistry of recent oxic and anoxic marine sediments: implications for the geological record, Mar. Geol., 113, 67-88, 1993.

Calvert, S. E. and Price, N. B.: Geochemistry of Namibian shelf sediments, in: Coastal Upwelling; Its Sediment Record, Part A: Responses of the Sedimentary Regime to Present Coastal Upwelling, edited by: Suess, E. and Thiede, J., NATO ASI Series, Plenum Press, 337-373, 1983.

Cauwet, G., Gadel, F., De Souza Sierra, M. M., Donard, O., and Ewald, M.: Contribution of the Rhone River to org. C inputs to the Northwestern Mediterranean Sea, Cont. Shelf Res., 10, 1025-1037, 1990.

Cheng, H., Edwards, R. L., Broecker, W. S., Denton, G. H., Kong, X., Wang, Y., Zhang, R., and Wang, X.: Ice Age Terminations, Science, 326, 248-252, 2009.

Clemens, S. C. and Prell,W. L.: A 350000 year summer-monsoon multiproxie stack from the Owen ridge, Northern Arabian Sea, Mar. Geol., 201, 35-51, 2003.

Clemens, S. C., Prell, W. L., and Sun, Y.: Orbital-scale timing and mechanisms driving Late Pleistocene Indo-Asian summer monsoons: Reinterpreting cave speleothem $\delta^{18} \mathrm{O}$, Paleoceanography, 25, PA4207, doi:10.1029/2010PA001926, 2010.

Conkright, M. E. and Boyer, T. P.: World Ocean Atlas 2001: Objective Analyses, Data Statistics, and Figures, CD-ROM Documentation, (National Oceanographic Data Center, Silver Spring), 2002.

Cosford, J., Qing, H., Yuan, D., Zhang, M., Holmden, C., Patterson, W., and Hai, C.: Millennial-scale variability in the Asian monsoon: evidence from oxygen isotope records from stalagmites in China, Palaeogeography, Palaeoclimatology, Palaeoecology, 266, 3-12, 2008.

Cowie, G.L., Calvert, S.E., Pedersen, T.F., Schulz, H., and von Rad, U.: Organic content and preservational controls in surficial shelf and slope sediments from the Arabian Sea (Pakistan margin), Mar. Geol., 161, 23-38, 1999.

Cowie, G.: The biogeochemistry of Arabian Sea surficial sediments: A review of recent studies, Prog. Oceanogr., 65, 260-289, 2005.

Crowley, T. J.: North Atlantic deep water cools the Southern Hemisphere, Paleoceanography, 7, 489-497, 1992.

Dansgaard, W., Johnsen, S. J., Clausen, H. B., Dahl-Jensen, D., Gundestrup, N. S., Hammer, C. U., Hvidberg, C. S., Steffensen, J. P., Sveinbjornsdottir, A. E., Jouzel, J., and Bond, G.: Evidence for general instability of past climate from a $250 \mathrm{kyr}$ ice core, Nature, 364, 218-219, 1993.

Deplazes, G., Lückge, A., Peterson, L. C., Timmermann, A., Hamann, Y., Hughen, K. A., Röhl, U., Laj, C., Cane, M. A., Sigman, D. M., and Haug, G. H.: Links between tropical rainfall and North Atlantic climate during the last glacial period, Nature Geosci., 6, 213-217, doi:10.1038/ngeo1712, 2013. 
Ding, Y., Li, C., and Liu, Y.: Overview of the South China Sea monsoon experiment, Adv. Atmos. Sci., 21, 343-360, doi:10.1007/BF02915563, 2004.

Dykoski, C. A., Edwards, R. L., Cheng, H., Yuan, D., Cai, Y., Zhang, M., Lin, Y., Qing, J., An, Z., Revenaugh, J.: A highresolution, absolute-dated Holocene and deglacial Asian monsoon record from Dongge Cave, China, Earth Planet. Sci. Lett., 233, 71-86, 2005.

EPICA Community Members: One-to-one hemispheric coupling of millennial polar climate variability during the last glacial, Nature, 444, 195-198, 2006.

Garcia, H. E., Locarnini, R. A., Boyer, T. P., and Antonov, J. I.: World Ocean Atlas 2005, Volume 3: Dissolved Oxygen, Apparent Oxygen Utilization, and Oxygen Saturation, (NOAA Atlas NESDIS 63), 2006.

Gribble, G. W.: Naturally occurring organohalogen compounds, Acc. Chem. Res., 31, 141-152, 1998.

Harvey, G. R.: A study of the chemistry of iodine and bromine in marine sediments, Mar. Chem., 8, 327-332,1980.

Heinrich, H.: Origin and consequences of cyclic ice rafting in the Northeast Atlantic Ocean during the past 130,000 years, Quat. Res., 29, 142-152, 1988.

Hendy, I. L. and Pedersen, T. F.: Is pore water oxygen content decoupled from productivity on the California Margin? Trace element results from Ocean Drilling Program Hole 1017E, San Lucia slope, California, Paleoceanography, 20, PA4026, doi:10.1029/2004PA001123, 2005.

Ivanochko, T. S., Ganeshrama, R. S., Brummer, G-J. B., Ganssen, G., Jung, S. J. A., Moreton, S. G., and Kroon, D.: Variations in tropical convection as an amplifier of global climate change at the millennial scale, Earth Planet. Sci. Lett., 235, 302-314, 2005.

Jung, S. J. A., Kroon, D., Ganssen, G., Peeters, F., and Ganeshrama, R.: Enhanced Arabian Sea intermediate water flow during glacial North Atlantic cold phases, Earth Planet. Sci. Lett., 280, 220228. doi:10.1016/j.epsl.2009.01.037, 2009.

Laskar, J., Robutel, P., Joutel, F., Gastineau, M., Correia, A. M. C., and Levrard, B.: A long-term numerical solution for the insolation quantities of the Earth, A\&A, 428, 261-285, 2004.

Lee, J. E., Risi, C., Fung, I., Worden, J., Scheepmaker, R. A., Lintner, B., and Frankenberg, C.: Asian monsoon hydrometeorology from TES and SCIAMACHY water vapor isotope measurements and LMDZ simulations: Implications for speleothem climate record interpretation, J. Geophys. Res., 117, D15112, doi:10.1029/2011JD017133, 2012.

Leuschner, D. C. and Sirocko, F.: The low-latitude monsoon climate during Dansgaard-Oeschger cycles and Heinrich events, Quat. Sci. Rev., 19, 243-254, 2000.

Martinez, P., Bertrand, P., Shimmield, G. B., Cockrane, K., Jorissen, F.J., Foster, J., and Dignan, M.: Upwelling intensity and ocean productivity changes off Cape Blanc (northwest Africa) during the last 70000 years: geochemical and micropalaeontological evidence, Mar. Geol., 158, 57-74, 1999.

Mayer, L. M., Schick, L. L., Allison, M. A., Ruttenberg, K. C., and Bentley, S. J.: Marine vs. terrigenous organic matter in Louisiana coastal sediments: The uses of bromine: organic carbon ratios, Mar. Chem., 107, 244-254, 2007.

Meehl, G. A.: The south Asian monsoon and the tropospheric biennial oscillation, J. Climate, 10, 1921-1943, 1997.
Nair, R. R., Ittekkot, V., Manganini, S.J., Ramaswamy, V., Haake, B., Degens, E. T., Desai, B. N., and Honjo, S.: Increased particle flux to the deep ocean related to monsoons, Nature, 338, 749$751,1989$.

NGRIP members: High-resolution record of Northern Hemisphere climate extending into the last interglacial period, Nature, 431, 147-151, 2004.

Pahnke, K. and Zahn, R..: Southern hemisphere water mass conversion linked to North Atlantic climate variability, Science, 307, 1741-1746, 2005.

Paillard, D., Labeyrie, L. D., and Yiou, P.: Macintosh program performs time-series analysis, Eas. Trans., 77, 379-379, 1996.

Pausata, F. S. R., Battisti, D. S., Nisancioglu, K. H., and Bitz, C. M.: Chinese stalagmite $\delta^{18} \mathrm{O}$ controlled by changes in the Indian monsoon during a simulated Heinrich event, Nature Geosci., 4, 474-480, doi:10.1038/ngeo1169, 2011.

Pedersen, T. F. and Price, N. B.: The geochemistry of iodine and bromine in sediments of the Panama Basin, J. Mar. Res, 38, 397 411, 1980.

Pichevin, L., Bard, E., Martinez, P., and Billy, I.: Evidence of ventilation changes in the Arabian Sea during the late Quaternary: Implication for denitrification and nitrous oxide emission, Global Biogeochem. Cy., 21, GB4008, doi:10.1029/2006GB002852, 2007.

Rasmussen, S. O., Andersen, K. K., Svensson, A. M., Steffensen, J. P., Vinther, B. M., Clausen, H. B., Siggaard-Andersen, M.L., Johnsen, S. J., Larsen, L. B., Dahl-Jensen, D., Bigler, M., Röthlisberger, R., Fischer, H., Goto-Azuma, K., Hansson, M. E., and Ruth, U.: A new Greenland ice core chronology for the last glacial termination, J. Geophys. Res., 111, D06102, doi:10.1029/2005JD006079, 2006.

Reichart, G. J., Lourens, L. J., and Zachariasse, W. J.: Temporal variability in the northern Arabian Sea oxygen minimum zone (OMZ) during the last 225000 years, Paleoceanography, 13, 607-621, 1998.

Rohling, E. J., Mayewski, P. A., and Challenor, P.: On the timing and mechanism of millennial-scale climate variability during the last glacial cycle, Clim. Dynam., 20, 257-267, 2003.

Rohling, E. J., Liu, Q. S., Roberts, A. P., Stanford, J. D., Rasmussen, S. O., Langen, P. L., and Siddall, M.: Controls on the East Asian monsoon during the last glacial cycle, based on comparison between Hulu Cave and polar ice-core records, Quat. Sci. Rev., 28, 3291-3302. doi:10.1016/j.quascirev.2009.09.007, 2009.

Sarma, V. V. S. S.: An evaluation of physical and biogeochemical processes regulating perennial suboxic conditions in the water column of the Arabian Sea, Global Biogeochem. Cy., 16, 1082, http://dx.doi.org/10.1029/2001GB001461, 2002.

Schlitzer, R.: Ocean Data View, (http://odv.awi.de), 2011.

Schulz, H., von Rad, U., and Erlenkeuser, H.: Correlation between Arabian Sea and Greenland climate oscillations of the past 110000 years, Nature, 393, 54-57, 1998.

Shi, Z., Liu, X., and Cheng, X.: Anti-phased response of northern and southern East Asian summer precipitation to ENSO modulation of orbital forcing, Quat. Sci. Rev., 40, 30-38, 2012.

Shimmield, G. B. and Pedersen, T. F.: The geochemistry of reactive trace metals and halogens in hemipelagic continental margin sediments, Critical Reviews in Aquatic Sciences, 3, 255-279, 1990.

Stuiver, M.: INTCAL98 radiocarbon age calibration, 24,000-0 cal BP, Radiocarbon, 40, 1041-1083, 1998. 
Van Pée, K.-H.: Biosynthesis of halogenated metabolites by bacteria, Annu. Rev. Microbiol., 50, 375-399, 1996.

Wang, Y. J., Cheng, H., Edwards, R. L., An, Z. S., Wu, J. Y., Shen, C.-C., and Dorale, J. A.: A high-resolution absolute-dated late Pleistocene monsoon record from Hulu Cave, China, Science, 294, 2345-2348, 2001.

Xue, F., Wang, H., and He, J.: Interannual Variability of Mascarene High and Australian High and Their Influences on East Asian Summer Monsoon, J. Meteorol. Soc. Japan, 82, 11731186, 2004.

Yuan, D., Cheng, H., Edwards, R. L., Dykoski, C. A., Kelly, M. J., Zhang, M., Qing, J., Lin, Y., Wang, Y., Wu, J., Dorale, J. A., An, Z., and Cai, Y.: Timing, duration, and transitions of the last interglacial Asian Monsoon, Science, 304, 575-578, 2004.
Ziegler, M., Jilbert, T., de Lange, G. J., Lourens, L. J., and Reichart, G. J.: Bromine counts from XRF scanning as an estimate of the marine organic carbon content of sediment cores, Geochem. Geophys. Geosyst., 9, Q05009, doi:10.1029/2007GC001932, 2008.

Ziegler, M., Lourens, L. J., Tuenter, E., Hilgen, F., Reichart, G. J., and Weber, N.: Precession phasing offset between Indian summer monsoon and Arabian Sea productivity linked to changes in Atlantic overturning circulation, Paleoceanography, 25, PA3213, doi:10.1029/2009PA001884, 2010. 